\title{
The impact of ICAM-1, CCL2 and TGM2 gene polymorphisms on differentiation syndrome in acute promyelocytic leukemia
}

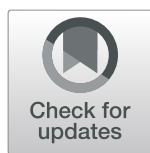

\author{
Zahra Mohammadzadeh", Azadeh Omidkhoda ${ }^{1 *}$, Bahram Chahardouli², Ghazaleh Hoseinzadeh', \\ Kamran Ali Moghaddam², Seyed Asadollah Mousavi ${ }^{2}$ and Shahrbano Rostami ${ }^{2 *}$
}

\begin{abstract}
Background: Although arsenic trioxide (ATO) and all-trans retinoic acid (ATRA) are well-tolerated and effective treatments for Acute Promyelocytic Leukemia (APL), Differentiation Syndrome (DS) is a lethal side effect in some patients. The pathogenesis of DS is complex and not well understood; however, it is considered as an inflammatory response due to cytokines release of differentiated cells. Moreover, adhesion molecules that are widely expressed on the surface of differentiated cells and gene expression changes of transglutaminase2 (TGM2) are mechanisms involved in the development of DS. The purpose of this study was to assess the association of single nucleotide polymorphisms (SNP) of Intercellular Adhesion Molecule-1 (ICAM-1), chemokine (C-C motif) ligand 2 (CCL2) and TGM2 as inflammatory factors with differentiation syndrome susceptibility.
\end{abstract}

Methods: DNA was extracted from 133 APL patients and 100 normal controls. Assessment according to the PETH EMA criteria revealed that $13.5 \%$ of these patients experienced differentiation syndrome. Tetra-ARMS PCR and PCRRFLP were done to amplify DNA fragments in APL patients with and without DS. Then DNA sequencing was done to validate the results. SNPStats, SPSS and Finch TV were used to analyze the results.

Results: A significant correlation was found between rs4811528 in the TGM2 gene and differentiation syndrome susceptibility ( $P=0.002,95 \% \mathrm{Cl}=1.74-18.81, \mathrm{OR}=5.72$ ) while rs5498 in ICAM-1, rs1024611 in CCL2, and rs7270785 in TGM2 genes showed no correlation with differentiation syndrome. The G allele of rs 7270785 and rs 4811528 showed a haplotypic association with differentiation syndrome $(P=0.03,95 \% \mathrm{Cl}=1.13-13.86, \mathrm{OR}=3.96)$.

Conclusions: AA genotype of the TGM2 SNP (rs4811528) may be a risk factor for development of DS in patients with APL following the use of ATRA/ATO.

Keywords: Acute Promyelocytic leukemia, Differentiation syndrome, ICAM-1, CCL2 chemokine, Transglutaminase II, SNPS

\footnotetext{
* Correspondence: a-omidkhoda@tums.ac.ir; rostamyshahrbano8@gmail.com

${ }^{1}$ Hematology and Blood Banking Department, School of Allied Medical

Sciences, Tehran University of Medical Sciences, Tehran, Iran

${ }^{2}$ Hematology-Oncology and Stem Cell Transplantation Research Center,

Tehran University of Medical Sciences, Tehran, Iran
}

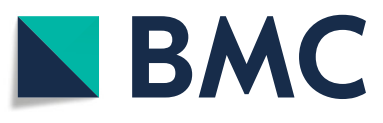

(c) The Author(s). 2021 Open Access This article is licensed under a Creative Commons Attribution 4.0 International License, which permits use, sharing, adaptation, distribution and reproduction in any medium or format, as long as you give appropriate credit to the original author(s) and the source, provide a link to the Creative Commons licence, and indicate if changes were made. The images or other third party material in this article are included in the article's Creative Commons licence, unless indicated otherwise in a credit line to the material. If material is not included in the article's Creative Commons licence and your intended use is not permitted by statutory regulation or exceeds the permitted use, you will need to obtain permission directly from the copyright holder. To view a copy of this licence, visit http://creativecommons.org/licenses/by/4.0/ The Creative Commons Public Domain Dedication waiver (http://creativecommons.org/publicdomain/zero/1.0/) applies to the data made available in this article, unless otherwise stated in a credit line to the data. 


\section{Background}

Acute Promyelocytic Leukemia (APL) is characterized by a reciprocal translocation between the long arms of chromosomes 15 and 17, t $(15 ; 17)$ (q21; q22), which results in a fusion between the promyelocytic leukemia (PML) gene and retinoic acid receptor alpha (RAR alpha). PML/RAR $\alpha$ homodimers inhibit the expression of differentiation genes in granulocytes [1, 2]. All-trans retinoic acid (ATRA) and arsenic trioxide (ATO), especially when combined compared to either one alone, are the most effective drugs for the treatment of APL, which induce the degradation of chimeric oncoprotein PML/ RAR $\alpha$ and APL cell differentiation [3, 4]. ATRA/ATO treatment can induce differentiation syndrome (DS) or retinoic acid syndrome (a life-threatening complication) in some patients [5]. According to the PETHEMA (Programa para el Tratamiento de Hemopatías Malignas) criteria, the presence of one or more of the following features may indicate a diagnosis of DS: hyperleucocytosis, respiratory distress, unexplained fever, hypotension, weight gain more than $5 \mathrm{~kg}$, acute renal failure, and a chest radiograph demonstrating pericardial effusion or pulmonary infiltrates [6-9]. The molecular and cellular mechanisms of DS are not fully known; however, it is believed that administration of ATRA/ATO leads to a systemic inflammatory response syndrome (SIRS) and massive gene expression changes in differentiating blast cells [9-11]. The proposed mechanisms include changes in the adhesion molecules, cytokine secretion, and enzymes during ATRA/ATO induced differentiation such as Intercellular Adhesion Molecule-1(ICAM-1), monocyte chemoattractant protein-1 (MCP-1/CCL2), and type-2 transglutaminase (TGM2/TG2) [10, 12-14]. ICAM-1 (CD54) is a single chain $76-110 \mathrm{kDa}$ glycoprotein and a member of the Ig superfamily located on chromosome 19p13 [15], MCP-1/CCL2 is a CC chemokine located on chromosome 17q11 [16], and TGM2 is a 74-80 kDa protein and a member of the transglutaminase family located on chromosome 20q11-12 [17, 18]. Single Nucleotide Polymorphisms (SNPs) SNPs are variations in the DNA sequence. SNPs are helpful in determining how individuals respond to diseases or interact with drugs and therapeutic procedures. Many studies have shown associations between polymorphisms and inflammatory disorders [19-21]. One study found an association between the AA genotype at ICAM-1 Exon 6 (E469K) and DS [3]. Considering the possible role of the polymorphisms of cell adhesion molecules, chemokines, and transglutaminase in DS pathogenesis, the aim of this study was to investigate the association of rs1024611 in CCL2, rs5498 in ICAM-1, and rs7270785 and rs4811528 in TGM2 with the development of differentiation syndrome in patients treated with ATRA/ ATO.

\section{Methods}

\section{Patients characteristics}

From 2012 to 2017, patients with APL who referred to the Hematology, Oncology, and Stem Cell Transplantation Research Center of Shariati hospital, Tehran, Iran were studied. All patients received ATRA-ATO as reported previously [22]. One hundred and thirty-three APL patients were selected based on availability of patient samples. According to the PETEHMA criteria (fever $\geq 38^{\circ} \mathrm{C}$, weight gain $>5 \mathrm{~kg}$, hypotension, dyspnea, LQTS (Long QT Syndrome) and acute renal failure), Eighteen selected APL patients were diagnosed with differentiation syndrome after receiving ATRA/ATO. Samples from 100 healthy volunteers were used as controls. The study was approved by the Ethics Committee of Tehran University of Medical Sciences (Ethics Code: IR.TUMS.SPH.REC.1397.269) and written informed consent was obtained from all participants.

\section{DNA isolation}

The genomic DNA of the samples was extracted from their peripheral blood in tubes containing ethylenediamine tetra acetic acid (EDTA) anticoagulants using the standard salting-out method. The concentration and the purity of the DNA samples were evaluated with a Nano Drop device (Thermo Fisher Scientific, USA).

\section{Tetra-ARMS PCR (tetra-primer ARMS PCR)}

The amplification-refractory mutation system polymerase chain reaction (Tetra-ARMS PCR) was used for detection of rs5498 in ICAM-1 and rs7270785 and rs4811528 in TGM2 with appropriate primer sets Table 1 . The reaction was performed in a total volume of $15 \mu \mathrm{l}$, containing $1 \mu \mathrm{l}$ genomic DNA $(60-80 \mathrm{ng} / \mu \mathrm{l})$, $7.5 \mu \mathrm{l} 1 \times$ Master Mix PCR (Ampliqon, Denmark), optimum forward and reverse inner primer ratio for rs5498, rs4811528 and rs7270785 (1:2, $1: 2$ and 1:4, respectively $(10 \mathrm{pmol}))$, and $0.2-0.5 \mu \mathrm{M}$ of each outer primer. The optimum PCR condition was $95^{\circ} \mathrm{C}$ for $3 \mathrm{~min}$ followed by 35 cycles $\left(95^{\circ} \mathrm{C}\right.$ for $15 \mathrm{~s}, 62^{\circ} \mathrm{C}$ for $20 \mathrm{~s}$, and $72{ }^{\circ} \mathrm{C}$ for $20 \mathrm{~s}$ in rs $5498 ; 95^{\circ} \mathrm{C}$ for $15 \mathrm{~s}, 62^{\circ} \mathrm{C}$ for $15 \mathrm{~s}$, and $72{ }^{\circ} \mathrm{C}$ for $25 \mathrm{~s}$ for rs 4811528 ; and $95^{\circ} \mathrm{C}$ for $15 \mathrm{~s}$, $68^{\circ} \mathrm{C}$ for $20 \mathrm{~s}$, and $72^{\circ} \mathrm{C}$ for $20 \mathrm{~s}$ for rs7270785) and a final extension at $72{ }^{\circ} \mathrm{C}$ for $6 \mathrm{~min}$. To visualize the results, $10 \mu \mathrm{l}$ PCR product was run on a $2 \%$ agarose gel containing $3 \mu \mathrm{l}$ loading dye.

\section{PCR-RFLP}

The CCL2 polymorphism (rs1024611) was detected by polymerase chain reaction-restriction fragment length polymorphism (PCR-RFLP) using forward and reverse primers (Table 1). The reaction was performed in a total volume of $15 \mu \mathrm{l}$, containing $1 \mu \mathrm{l}$ genomic DNA (60-80 ng/ $\mu \mathrm{l}), 7.5 \mu \mathrm{l} 1 \times$ Master Mix PCR (Ampliqon, Denmark), 
Table 1 The primer sequences used for gene PCR

\begin{tabular}{|c|c|c|c|}
\hline \multirow{2}{*}{$\frac{\text { SNP ID }}{\text { rs5498 }}$} & \multicolumn{2}{|c|}{ Primer sequences } & \multirow{2}{*}{$\frac{\text { Product size (bp) }}{\text { G allele (189) }}$} \\
\hline & F inner & GAGCACTCAAGGGGAGGTCACCCTCG & \\
\hline & R inner & TCACTCACAGAGCACATTCACGGTCACATT & A allele (274) \\
\hline & F outer & ATCTCATCGTGTIITTCCAGATGGCCCC & Control band (407) \\
\hline & R outer & CCCATTATGACTGCGGCTGCTACCACA & \\
\hline \multirow[t]{4}{*}{ rs4811528 } & F inner & ATAAACCTTGGCAAGCTCAAGGTCAGGGTT & A allele (179) \\
\hline & R inner & САCTCCTCCCACCTTAAGGGCTTCTCC & G allele (259) \\
\hline & F outer & GCTGTGTTGCTGTGTGAGCCTGGATAAG & Control band (383) \\
\hline & R outer & TGGAATAGTCGATGGTGAGCAGGAGACC & \\
\hline \multirow[t]{4}{*}{ rs7270785 } & F inner & СТTATCTCAAACCATAACCAACCTGCACC & T allele (201) \\
\hline & R inner & CAAGCTACAATGTTCCCACACAGGAGCA & G allele (291) \\
\hline & F outer & CAAGCTACAATGTTCCCACACAGGAGCA & Control band (435) \\
\hline & R outer & СTTCTCCAATTGTCTGGGCAGCGTAGTG & \\
\hline \multirow[t]{2}{*}{ rs1024611 } & F outer & GGCTGAGTGTTCACATAGGCTTCTGAGT & Control band (281) \\
\hline & R outer & AACTTCCAAAGCTGCCTCCTCAGAGT & \\
\hline
\end{tabular}

F Forward, $R$ Reverse

and $0.3 \mu \mathrm{M}$ of each outer primer. PCR was performed by denaturing the samples at $95^{\circ} \mathrm{C}$ for $3 \mathrm{~min}$ followed by 40 cycles including $95^{\circ} \mathrm{C}$ for $15 \mathrm{~s}, 64{ }^{\circ} \mathrm{C}$ for $20 \mathrm{~s}, 72^{\circ} \mathrm{C}$ for $25 \mathrm{~s}$, and final extension at $72^{\circ} \mathrm{C}$ for $6 \mathrm{~min}$. For RFLP analysis, the PCR product was digested with $10 \mathrm{U} / \mu \mathrm{l}$ PVUח and $10 \mathrm{x}$ buffer G (Thermo Scientific, Massachusetts, United States) and incubated at $37^{\circ} \mathrm{C}$ for $16 \mathrm{~h}$. The digested PCR products were separated on a $2 \%$ agarose gel.

\section{Validation assay}

DNA sequencing was done to validate the results. The same outer primers of Tetra-ARMS PCR and PCR-RFLP in conventional PCR were used to amplify the regions containing SNPs. Then, the cycle sequencing reaction was done using the Big Dye Terminator v3.1 Cycle Sequencing kit (Applied Biosystems, Foster City, CA, USA) according to the manufacturer's instructions and the samples were sequenced using the 3130 xl Genetic Analyzer ABI.

\section{Statistical analysis}

The Hardy-Weinberg equilibrium (HWE) was applied to assess the deviation of the genotype or allele frequency. The demographic and hematologic data were distributed normally. Pearson's Chi square, Mann-Whitney U-test, and t-test were used for statistical comparison. The SPSS version 20.0 (IBM, NY, USA) was used for data analysis. Multiple logistic regression models (codominant, dominant, recessive, over dominant and log-additive) were applied to analyze the correlation between the SNP data and disease phenotype (odds ratio) with 95\% confidence interval was calculated using the SNPStats software. $P$ values less than 0.05 were considered significant. The
Finch TV software version 1.4.0 was used to interpret the sequencing results.

\section{Results}

\section{Patients 'baseline characteristics}

One hundred and thirty-three APL patients (74 females and 59 males) with a mean age of $36 \pm 13.9$ years and 100 healthy volunteers (51 females and 49 males) with a mean age of $34 \pm 13.5$ years were included in the study.

There were no significant differences between APL patients and healthy controls $(p$ value $<0.05)$. Table 2 presents demographics and laboratorial findings of APL patients, with and without DS. According to this table, no significant differences were detected between the two groups.

\section{Electrophoresis and sequencing results}

The product of the tetra-primer ARMS PCR specific for rs5498 contained 3 fragments $(407 \mathrm{bp}, 274 \mathrm{bp}$ and 189 $\mathrm{bp}$ ) in the AG heterozygous genotype and 2 fragments in the homozygous mutant and wild types (GG resulting in $189 \mathrm{bp}$ and $407 \mathrm{bp}$ fragments, and AA resulting in

Table 2 Demographics and laboratorial findings of APL patients with and without DS

\begin{tabular}{llll}
\hline Characteristics & DS & No DS & P value \\
\hline Number of samples & 18 & 115 & \\
Gender (Male/Female) & $7 / 11$ & $52 / 63$ & 0.6 \\
Age (years) & $37.8 \pm 15.8$ & $34.6 \pm 13$ & 0.4 \\
WBC counts $\left(/ \mu \mathrm{l}^{*} 10^{3}\right)$ & $61.3 \pm 9.9$ & $65.5 \pm 12.2$ & 0.4 \\
$\mathrm{Hb}(\mathrm{g} / \mathrm{dl})$ & $1.7 \pm 8$ & $2.6 \pm 9$ & 0.1 \\
Platelets $\left(/ \mu \mathrm{l}^{*} 10^{3}\right)$ & $53.4 \pm 45$ & $57.2 \pm 76$ & 0.2 \\
\hline
\end{tabular}

Values presented as mean $( \pm \mathrm{SD}), \mathrm{Hb}$ Hemoglobin 
$274 \mathrm{bp}$ and $407 \mathrm{bp}$ fragments) Fig. 1a. In rs7270785, the TG heterozygous genotype contained 3 fragments (435 bp, $291 \mathrm{bp}$ and $201 \mathrm{bp}$ ), the GG homozygous mutant genotype contained 2 fragments (435 bp and $291 \mathrm{bp}$ ), and the TT homozygous wild type contained 2 fragments (435 bp and 201 bp) Fig. 1b. In rs4811528, the AG heterozygous genotype had 3 fragments (383 bp, $259 \mathrm{bp}$ and $179 \mathrm{bp}$ ), the GG mutant homozygous genotype had 2 fragments (383 bp and $259 \mathrm{bp}$ ), and the AA homozygous wild type had 2 fragments (383 bp and $179 \mathrm{bp}$ ) Fig. 1c. For rs1024611, the amplified fragment length was $281 \mathrm{bp}$. Digestion with PVUח produced 3 fragments of $281 \mathrm{bp}, 160$ bp and $121 \mathrm{bp}$ in the CT heterozygous genotype and 2 fragments of $160 \mathrm{bp}$ and $121 \mathrm{bp}$ in the CC homozygous mutant genotype while the TT homozygous wild type remained uncut Fig. 1d. A heterozygous sample of each SNP was selected that contained both mutant and wild type alleles; then, DNA sequencing confirmed the results obtained by T-ARMS PCR.

\section{Distribution of genotype and allele frequency}

The genotype and allele frequencies for rs5498, rs4811528, rs7270785, and rs1024611 polymorphisms in case and control groups are presented in Table 3. The distribution of genotypes was consistent with HWE in both groups $(P>0.05)$. The frequency of the genotypes of TGM2 gene polymorphism (rs4811528) was AG= $44 \%, \mathrm{AA}=37 \%$, and $\mathrm{GG}=19 \%$ in 133 patients with $\mathrm{APL}$ and $\mathrm{AA}=48 \%, \quad \mathrm{AG}=41 \%$, and $\mathrm{GG}=11 \%$ in 100 controls.

\section{Correlation of ICAM-1, CCL2 and TGM2 polymorphisms with differentiation syndrome in APL patients}

Five genetic models (codominant, dominant, recessive, over dominant and log-additive) were applied to analyze the associations between ICAM-1, CCL2 and TGM2 polymorphisms and differentiation syndrome in patients with APL. The results of the genetic models showed that TGM2 polymorphism (rs4811528) was significantly associated with susceptibility to differentiation syndrome [codominant $\quad(\mathrm{OR}=5.61 ; \quad 95 \% \quad \mathrm{CI}=1.53-20.48, \quad P=$ 0.009), dominant $(\mathrm{OR}=5.72 ; 95 \% \mathrm{CI}=1.74-18.81, P=$ $0.002)$, over dominant $(\mathrm{OR}=4.06 ; 95 \% \mathrm{CI}=1.14-14.44$, $P=0.02)$, and log-additive $(\mathrm{OR}=3.78 ; 95 \% \mathrm{CI}=1.37-$ $10.44, P=0.004)]$ Table 4 . There was no significant association between ICAM-1 (rs5498), CCL2 (rs1024611),
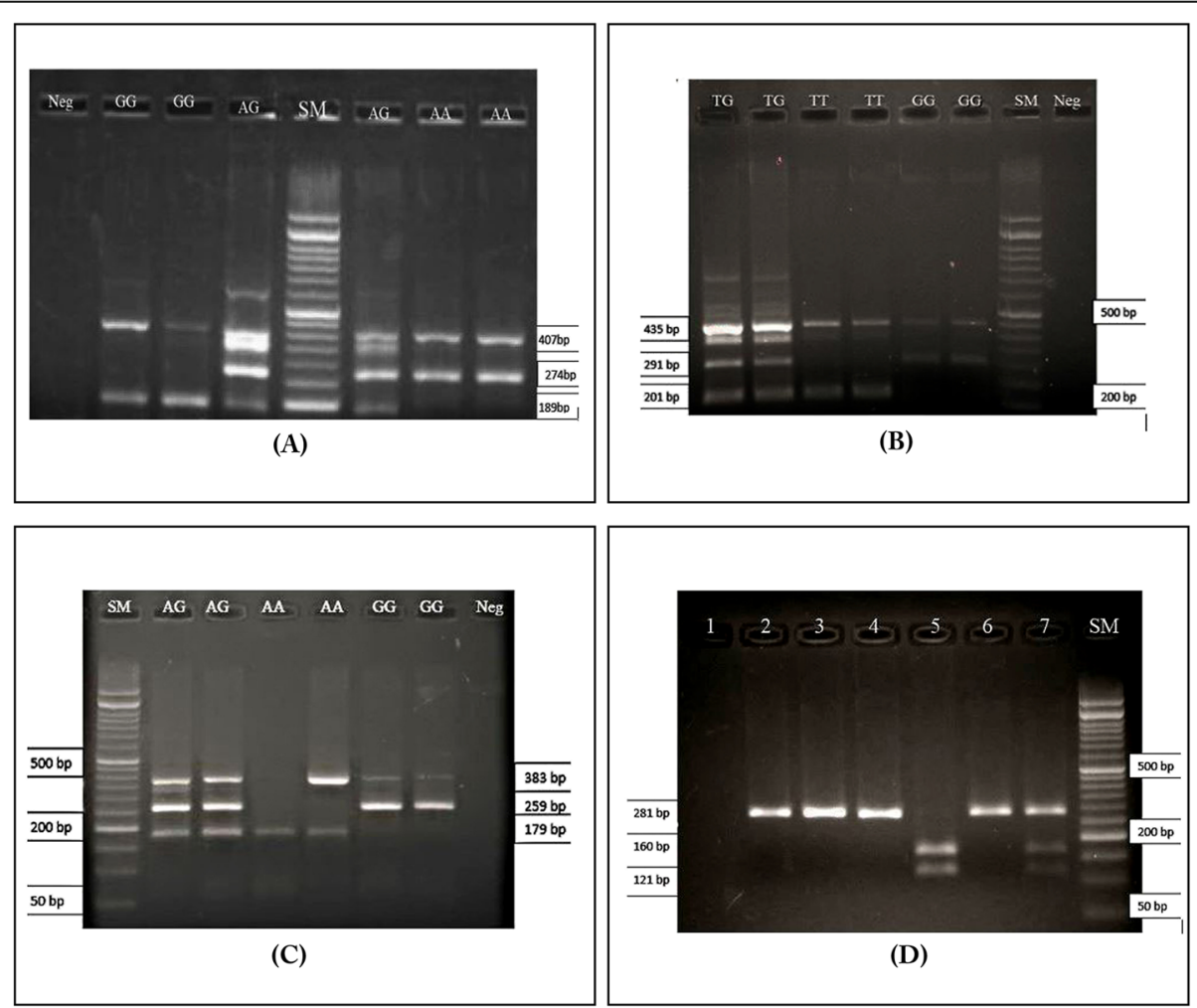

Fig. 1 Agarose gel electrophoresis of genotype variation of rs5498, rs7270785, rs4811528 and PCR-RFLP for rs1024611. Genotype variation of rs5498 determined by control fragment (407 bp), specific fragment of A allele (274 bp) and G allele (189 bp) a. Genotype variation of rs7270785 determined by control fragment (435 bp), specific fragment of $\mathrm{G}$ allele (291 bp) and T allele (201 bp) b. Genotype variation of rs4811528 determined by control fragment (383 bp), specific fragment of $\mathrm{G}$ allele (259 bp) and A allele (179 bp) c. For rs 1024611, 1 represent negative control; 2 (undigested) and 3 (digested) represent T allele (281 bp);4 (undigested) and 5 (digested) represent C allele (160 bp and 121 bp); 6 (undigested) and 7 (digested) represent T and C allele (281 bp, $160 \mathrm{bp}$ and $121 \mathrm{bp}) \mathbf{d}$ 
Table 3 Genotypes and allele frequencies of polymorphisms analyzed in APL Patients and controls

\begin{tabular}{|c|c|c|c|c|c|c|c|c|}
\hline \multirow[b]{2}{*}{ SNP ID } & \multicolumn{4}{|c|}{ APL Patients } & \multicolumn{4}{|l|}{ controls } \\
\hline & $\begin{array}{l}\text { Genotype } \\
(N)\end{array}$ & $\begin{array}{l}\text { Genotype Frequency } \\
\text { (\%) }\end{array}$ & $\begin{array}{l}\text { Allele } \\
(N)\end{array}$ & $\begin{array}{l}\text { Allele Frequency } \\
(\%)\end{array}$ & Genotype & $\begin{array}{l}\text { Genotype Frequency } \\
\text { (\%) }\end{array}$ & $\begin{array}{l}\text { Allele } \\
(N)\end{array}$ & $\begin{array}{l}\text { Allele Frequency } \\
\text { (\%) }\end{array}$ \\
\hline \multirow[t]{3}{*}{ rs5498 } & AA (39) & 29 & A (150) & 56 & AA & 30 & A (112) & 56 \\
\hline & AG (72) & 54 & $G(116)$ & 44 & $A G$ & 52 & G (88) & 44 \\
\hline & GG (22) & 17 & & & GG & 18 & & \\
\hline \multirow[t]{3}{*}{ rs4811528 } & $\mathrm{AA}(50)$ & 37 & A (158) & 59 & $\mathrm{AA}$ & 48 & A (137) & 68 \\
\hline & AG (58) & 44 & G (108) & 41 & $A G$ & 41 & G (63) & 32 \\
\hline & GG (25) & 19 & & & GG & 11 & & \\
\hline \multirow[t]{3}{*}{ rs7270785 } & Tा (38) & 29 & $\mathrm{~T}(148)$ & 56 & $\pi$ & 25 & T (108) & 54 \\
\hline & TG (72) & 54 & G (118) & 44 & $\mathrm{TG}$ & 58 & G (92) & 46 \\
\hline & GG (23) & 17 & & & GG & 17 & & \\
\hline \multirow[t]{3}{*}{ rs1024611 } & $\Pi(61)$ & 46 & $\mathrm{~T}(181)$ & 68 & $\Pi$ & 54 & T (144) & 72 \\
\hline & TC (59) & 44 & C (85) & 32 & $\mathrm{TC}$ & 36 & $C(56)$ & 28 \\
\hline & CC (13) & 10 & & & CC & 10 & & \\
\hline
\end{tabular}

and TGM2 (rs7270785) polymorphisms and DS (data not shown). The 2-SNP haplotypes analysis also revealed a haplotypic association between the rs7270785rs4811528 haplotypes of TGM2 gene with DS development in $\mathrm{G}$ allele $(\mathrm{OR}=3.96 ; 95 \% \mathrm{CI}=1.13-13.86, P=$ $0.033)$ Table 5.

\section{Discussion}

Differentiation syndrome (DS) is a life-threatening complication characterized by respiratory distress, unexplained fever, hypotension, weight gain, interstitial pulmonary infiltrates, pleural or pericardial effusion, and acute renal failure as described by Frankel et al. in 1992 $[7,23]$. Although the pathogenesis of DS is complex and not well understood, several molecular and cellular mechanisms are involved in the development of DS. ATRA is thought to (a) lead to the release of a variety of cytokines (especially inflammatory cytokines) by differentiating blast cells and (b) induce changes in the adhesive properties of blasts cells as well as massive changes in gene expression, including downregulation of cell proliferation of related genes and induction of genes involved in immune function $[9,24]$. Finally, ATRA induces a systemic inflammatory response syndrome (SIRS) that manifests as fever, tachycardia and tachypnea and can progress to shock if left untreated [9]. The incidence of DS in APL patients ranges from 2 to 27\%, possibly due to the heterogeneity and range of clinical symptoms as well as inaccuracy of diagnostic criteria [25]. In the current study, DS was diagnosed in 18 of 133 APL patients (13.5\%) according to the PETEHMA criteria, including fever (temperature $\geq 38^{\circ} \mathrm{C}$ ), weight gain $>5 \mathrm{~kg}$, hypotension, dyspnea, long QT syndrome, and acute renal failure after taking ATRA/ATO. This is the first study of the role of several polymorphisms (ICAM-1, CCL2 and TGM2 genes) in the susceptibility of APL patients receiving ATO/ATRA to differentiation syndrome. MCP-1 regulates the migration of

Table 4 Analysis of association of TGM2 polymorphism (rs4811528) with the development of DS in APL patients

\begin{tabular}{|c|c|c|c|c|c|c|c|}
\hline Model & Genotype & DS (\%) & No DS (\%) & OR $(95 \% \mathrm{Cl})$ & $P$-value & AIC & BIC \\
\hline \multirow[t]{3}{*}{ Codominant } & $\mathrm{A} / \mathrm{A}$ & $13(72.2)$ & $37(32.2)$ & 1.00 & 0.0096 & 90.2 & 104.7 \\
\hline & $\mathrm{A} / \mathrm{G}$ & $4(22.2)$ & $54(47)$ & $5.61(1.53-20.48)$ & & & \\
\hline & $\mathrm{G} / \mathrm{G}$ & $1(5.6)$ & $24(20.9)$ & $6.14(0.70-53.45)$ & & & \\
\hline \multirow[t]{2}{*}{ Dominant } & $\mathrm{A} / \mathrm{A}$ & $13(72.2)$ & $37(32.2)$ & 1.00 & 0.0023 & 88.2 & 99.8 \\
\hline & $A / G-G / G$ & $5(27.8)$ & $78(67.8)$ & $5.72(1.74-18.81)$ & & & \\
\hline \multirow[t]{2}{*}{ Recessive } & $\mathrm{A} / \mathrm{A}-\mathrm{A} / \mathrm{G}$ & $17(94.4)$ & 91 (79.1) & 1.00 & 0.24 & 96.2 & 107.7 \\
\hline & $\mathrm{G} / \mathrm{G}$ & 1 (5.6) & $24(20.9)$ & $3.03(0.36-25.25)$ & & & \\
\hline \multirow[t]{2}{*}{ Over dominant } & $\mathrm{A} / \mathrm{A}-\mathrm{G} / \mathrm{G}$ & $14(77.8)$ & $61(53)$ & 1.00 & 0.02 & 92.1 & 103.6 \\
\hline & $A / G$ & $4(22.2)$ & $54(47)$ & $4.06(1.14-14.44)$ & & & \\
\hline Log-additive & - & - & - & $3.78(1.37-10.44)$ & 0.004 & 89.2 & 100.8 \\
\hline
\end{tabular}

AIC Akaike Information criterion, BIC Bayesian Information 
Table 5 Analysis of Haplotypic effect of rs4811528 and rs7270785 with the development of DS in APL patients

\begin{tabular}{lllll}
\hline rs7270785 & rs4811528 & Frequency & OR $(\mathbf{9 5 \%}$ Cl) & $P$-value \\
\hline T & A & 0.43 & 1.00 & 0.033 \\
G & G & 0.27 & $3.96(1.13-13.86)$ & \\
G & A & 0.17 & $1.47(0.55-3.95)$ & 0.45 \\
$\mathrm{~T}$ & $\mathrm{G}$ & 0.13 & $6.06(0.67-54.75)$ & 0.11 \\
\hline
\end{tabular}

monocytes/macrophages to tissues and is required for response to inflammation and routine immunological surveillance of tissues [26]. An A to G single nucleotide polymorphism (SNP) in the CCL2 enhancer region (rs1024611, originally designated as $-2518 \mathrm{G}$ or $-2578 \mathrm{G}$ ) has been associated with several chronic inflammatory conditions such as systemic lupus erythematosus (SLE) and rheumatoid arthritis [26-28]. In the present study, no association was found between this polymorphism and the development of differentiation syndrome. ICAM-1 is involved in cell adhesion and signaling, plays an important role in tumor progression and tumorigenesis, specifically by facilitating tumor invasion, and is associated with susceptibility to many cancers, including acute promyelocytic leukemia (APL) [14, 15]. Dore et al. found an association between development of DS and the AA genotype at codon 469 of ICAM-1 [3]. However, the present study showed no significant association between exon 6 (E469K) of ICAM-1 polymorphism and DS. The inclusion and exclusion criteria of the patients with DS and the prescribed medicines were different between the present study and the study by Dore et al. Type-2 transglutaminase (TGM2/TG2) is emerging as a multifunctional enzyme that is capable of promoting specialized enzyme functions under regulation by allosteric effectors depending on its cellular location such as angiogenesis, cell growth/differentiation, and cell death $[17,18]$. TGM2 acts as a $G$ protein in signal transduction processes and is involved in the pathophysiology of various inflammatory conditions. TGM2 is associated with 329 diseases, including immune system, endocrine, metabolic, cardiovascular, epidermal, renal and hematological diseases [17]. Bradford et al. genotyped eight SNPs (rs2076380, rs7270785, rs4811528, rs2284879, rs6023526, rs2268909, rs17789815 and rs1555074) related to the TGM2 gene in individuals with schizophrenia in a British population. The rs7270785rs4811528 haplotypes showed the strongest association with schizophrenia, and the authors suggested that the TGM2 gene might be involved in schizophrenia in the British population [12]. Wang et al. found no genetic association between four SNPs (rs2076380, rs7270785, rs4811528, and rs6023526) related to the TGM2 gene and schizophrenia in a Chinese population [29]. Csomós et al. reported that TGM2 played an important role in neutrophil granulocyte differentiation and gene expression and argued that reduced expression of TGM2 in the NB4 model of acute promyelocytic leukemia might suppress effector functions of neutrophil granulocytes and attenuate the ATRA-induced inflammatory phenotype of DS [10]. According to Jambrovics et al., TGM2 expression is induced by all-trans retinoic acid in differentiated NB4 cells and nuclear factor kappa-light-chain (NF-kB) signaling network is responsible for driving pathogenic processes by initiating an inflammatory cascade through over-expression of interleukin 1 beta (IL$1 \beta)$, numerous cytokines, and tumor necrosis factor alpha (TNF- $\alpha$ ) [30]. A limitation of the present study was that the number of patients with DS was relatively small and further studies in a bigger population with DS are necessary to confirm the findings.

\section{Conclusion}

AA genotype of the TGM2 SNP (rs4811528) may be a risk factor for development of DS in patients with APL following the use of ATRA/ATO.

\section{Abbreviations \\ APL: Acute Promyelocytic Leukemia; ATRA: All Trans Retinoic Acid; ATO: Arsenic Trioxide; SNP: Single Nucleotide Polymorphism; CCL2: CC motif Chemokine Ligand 2; ICAM-1: Intercellular Adhesion Molecule-1; DS: Differentiation Syndrome; PETHEMA: Programa para el Tratamiento de Hemopatías Malignas; PCR: Polymerase Chain Reaction; RFLP: Restriction Fragment Length Polymorphism; ARMS: The Amplification-refractory Muta- tion System; LQTS: Long QT Syndrome; TGM2: Transglutaminase 2}

\section{Acknowledgements}

This study was supported by Hematology, Oncology, and Stem Cell Transplantation Research Center and Allied School of Medical Sciences of Tehran University of Medical Sciences.

\section{Authors' contributions}

ZM: Acquired data, Drafted the manuscript. AO: Originated the study and substantively revised manuscript. BC: Acquired and interpreted data. GH: Performed statistical analysis, interpreted data. KAM: Design some part of the work. SAM: Design some part of the work. SHR: Made substantial contributions to the conception, design of the work. All authors have approved the submitted version and have agreed both to be personally accountable for the author's own contributions and to ensure that questions related to the accuracy or integrity of any part of the work, even ones in which the author was not personally involved, are appropriately investigated, resolved, and the resolution documented in the literature. The authors read and approved the final manuscript.

\section{Funding}

Not applicable.

\section{Availability of data and materials}

The datasets used and analyzed during the current study are available from the corresponding author on reasonable request.

Ethics approval and consent to participate

The study was approved by the Ethics Committee of Tehran University of Medical Sciences (Ethics Code: IR.TUMS.SPH.REC.1397.269) and written

informed consent was obtained from all participants.

Consent for publication

Not applicable. 


\section{Competing interests}

The authors declare that they have no competing interests.

Received: 3 October 2020 Accepted: 2 January 2021

Published online: 09 January 2021

\section{References}

1. Deschler B, Lübbert M. Acute myeloid leukemia: epidemiology and etiology. Cancer. 2006;107(9):2099-107.

2. Wang Z-Y, Chen Z. Acute promyelocytic leukemia: from highly fatal to highly curable. Blood. 2008;111(5):2505-15.

3. Dore Al, Santana-Lemos BA, Coser VM, Santos FL, Dalmazzo LF, Lima AS, et al. The association of ICAM-1 exon 6 (E469K) but not of ICAM-1 exon 4 (G241R) and PECAM-1 exon 3 (L125V) polymorphisms with the development of differentiation syndrome in acute promyelocytic leukemia. J Leukoc Biol. 2007:82(5):1340-3.

4. Luesink M, Pennings JL, Wissink WM, Linssen PC, Muus P, Pfundt R, et al. Chemokine induction by all-trans retinoic acid and arsenic trioxide in acute promyelocytic leukemia: triggering the differentiation syndrome. Blood. 2009:114(27):5512-21.

5. Tsai WH, Shih CH, Lin CC, Ho CK, Hsu FC, Hsu HC. MCP-1 in the migration of differentiated leukemic cells toward alveolar epithelial cells. Eur Respir J. 2008;31(5):957-62.

6. Luesink $\mathrm{M}$, Jansen $\mathrm{JH}$. Advances in understanding the pulmonary infiltration in acute promyelocytic leukaemia. Br J Haematol. 2010;151(3):209-20.

7. Rego EM, Santana-Lemos BA, Tamarozzi MB. Differentiation syndrome in acute promyelocytic leukemia: pathogenesis and risk factors. Rev Bras Hematol Hemoter. 2008;30:33-6.

8. Sanz MA, Grimwade D, Tallman MS, Lowenberg B, Fenaux P, Estey EH, et al. Management of acute promyelocytic leukemia: recommendations from an expert panel on behalf of the European LeukemiaNet. Blood J Am Soc Hematol. 2009;113(9):1875-91.

9. Stahl M, Tallman MS. Differentiation syndrome in acute promyelocytic leukaemia. Br J Haematol. 2019.

10. Csomós K, Német I, Fésüs L, Balajthy Z. Tissue transglutaminase contributes to the all-trans-retinoic acid-induced differentiation syndrome phenotype in the NB4 model of acute promyelocytic leukemia. Blood. 2010;116(19):3933-43.

11. Rego EM, De Santis GC. Differentiation syndrome in promyelocytic leukemia: clinical presentation, pathogenesis and treatment. Med J Hematol Infect Dis. 2011;3(1):e2011048.

12. Bradford M, Law MH, Stewart AD, Shaw DJ, Megson IL, Wei J. The TGM2 gene is associated with schizophrenia in a British population. Am J Med Genet B Neuropsychiatr Genet. 2009;150(3):335-40

13. Zablotna M, Sobjanek M, Purzycka-Bohdan D, Szczerkowska-Dobosz A Nedoszytko B, Nowicki R. The-2518 a/G MCP-1 and-403 G/a RANTES promoter gene polymorphisms are associated with psoriasis vulgaris. Clin Exp Dermatol. 2016;41(8):878-83.

14. Zhang X, Huang J, Bai J, Lu W, Zhang M, Mei H. Association of Polymorphisms in intercellular adhesion molecule 1 (ICAM-1) gene with Cancer susceptibility: a meta-analysis of 14 case-control studies. Med Sci Monit. 2016;22:569.

15. Cheng D, Liang B. Intercellular adhesion molecule-1 (ICAM-1) polymorphisms and cancer risk: a meta-analysis. Iran J Public Health. 2015; 44(5):615.

16. Deshmane SL, Kremlev S, Amini S, Sawaya BE. Monocyte chemoattractant protein-1 (MCP-1): an overview. J Interf Cytokine Res. 2009;29(6):313-26.

17. Bianchi N, Bianchi S, Bergamini CM. Spotlight on the transglutaminase 2 gene: a focus on genomic and transcriptional aspects. Biochem J. 2018:1643-67.

18. lismaa SE, Mearns BM, Lorand L, Graham RM. Transglutaminases and disease: lessons from genetically engineered mouse models and inherited disorders. Physiol Rev. 2009;89(3):991-1023.

19. Cimino L, Boiardi L, Aldigeri R, Casali B, Nicoli D, Farnetti E, et al. G/R 241 polymorphism of intercellular adhesion molecule 1 (ICAM-1) is associated with Fuchs uveitis. Invest Ophthalmol Vis Sci. 2010:51(9):4447-50.

20. Li H, Jin Z, Li X, Wu L, Jin J. Associations between single-nucleotide polymorphisms and inflammatory bowel disease-associated colorectal cancers in inflammatory bowel disease patients: a meta-analysis. Clin Transl Oncol. 2017:19(8):1018-27.

21. Sergi C, Kassam S, Meyer P, Corfield A. Single nucleotide polymorphisms (SNPs): history, biotechnological outlook and practical applications. Curr Pharmacogenom. 2005:3.
22. Ghavamzadeh A, Alimoghaddam K, Rostami S, Ghaffari SH, Jahani M, Iravani $\mathrm{M}$, et al. Phase II study of single-agent arsenic trioxide for the front-line therapy of acute promyelocytic leukemia. J Clin Oncol. 2011;29(20):2753-7.

23. De Santis GC, de Barros Tamarozzi M, Sousa RB, Moreno SE, Secco D, Garcia $A B$, et al. Adhesion molecules and differentiation syndrome: phenotypic and functional analysis of the effect of ATRA, As203, phenylbutyrate, and G-CSF in acute promyelocytic leukemia. Haematologica. 2007;92(12):1615-22.

24. Luesink M, Pennings JL, Wissink WM, Linssen PC, Muus P, Pfundt $R$, et al. Chemokine induction by all-trans retinoic acid and arsenic trioxide in acute promyelocytic leukemia: triggering the differentiation syndrome. Blood J Am Soc Hematol. 2009:114(27):5512-21.

25. Birendra K, DiNardo CD. Evidence for clinical differentiation and differentiation syndrome in patients with acute myeloid leukemia and IDH1 mutations treated with the targeted mutant IDH1 inhibitor, AG-120. Clin Lymp Myeloma Leuk. 2016;16(8):460-5.

26. Umare VD, Pradhan VD, Rajadhyaksha AG, Ghosh K, Nadkarni AH. A functional SNP MCP-1 (- 2518A/G) predispose to renal disorder in Indian systemic lupus Erythematosus patients. Cytokine. 2017;96:189-94.

27. Masselli E, Carubbi C, Cambò B, Pozzi G, Gobbi G, Mirandola P, et al. The$2518 \mathrm{a} / \mathrm{G}$ polymorphism of the monocyte chemoattractant protein-1 as a candidate genetic predisposition factor for secondary myelofibrosis and biomarker of disease severity. Leukemia. 2018:1.

28. Sharma NK, Sharma K, Singh R, Sharma SK, Anand A. CCL2 single nucleotide polymorphism of rs1024611 implicates prominence of inflammatory cascade by univariate modeling in Indian AMD. PloS One. 2018;13(4): e0193423.

29. Wang J, Liu Y, Wang Z, Du W, Hui L, Zhao X, et al. Lack of genetic association of the TGM2 gene with schizophrenia in a Chinese population. Psychiatr Genet. 2015;25(6):259-62.

30. Jambrovics K, Uray IP, Keresztessy Z, Keillor JW, Fésüs L, Balajthy Z. Transglutaminase 2 programs differentiating acute promyelocytic leukemia cells in all-trans retinoic acid treatment to inflammatory stage through NFkB activation. Haematologica. 2019:104(3):505-15.

\section{Publisher's Note}

Springer Nature remains neutral with regard to jurisdictional claims in published maps and institutional affiliations.
Ready to submit your research? Choose BMC and benefit from:

- fast, convenient online submission

- thorough peer review by experienced researchers in your field

- rapid publication on acceptance

- support for research data, including large and complex data types

- gold Open Access which fosters wider collaboration and increased citations

- maximum visibility for your research: over $100 \mathrm{M}$ website views per year

At $\mathrm{BMC}$, research is always in progress.

Learn more biomedcentral.com/submissions 